\title{
MUTU PELAYANAN DAN KEPUASAN PASIEN DI INSTALASI RAWAT INAP RUANG DAHLIA RSUD KOTA MADIUN
}

\author{
Suhadi Prayitno \\ Program Studi Kesehatan Masyarakat STIKES Bhakti Husada Mulia Madiun
}

\begin{abstract}
Service efforts undertaken by the Hospital was to improve the quality of health services quality and affordable by the community in order to improve public health status.Quality of service should be done by Hospital to improve patient satisfaction as a service user. The objective was to analyze association between service quality and patient satisfaction at Dahlia room,Regional Public Hospital Madiun .An observational analysis was conducted with cross-sectional study design. Samples were 78 using purposive sampling techniques. Data were analyzed by chi-square. This study showed that $56,4 \%$ respondents said that the quality of service was good. There were $52,6 \%$ respondents not satisfied with quality of service. Bivariate analysis showed association between service quality and patient satisfaction $(\mathrm{p}=0,014)$. There were an association between service quality and patient satisfaction. Madiun City General Hospital should improve the quality of service so that all patients are satisfied with the services provided.
\end{abstract}

Keywords: Service quality, patient satisfaction, hospital

\section{PENDAHULUAN}

Rumah Sakit merupakan institusi pelayanan yang sangat komplek, padat profesi dan padat modal. Agar Rumah Sakit dapat melaksanakan fungsi dengan baik, maka di Rumah Sakit harus memiliki sumber daya manusia, sarana dan prasarana peralatan yang memadai serta dikelola secara profesional (Departemen Kesehatan RI, 2010). Hasil penelitian Badan Pusat Statistik tahun 2012 menyatakan bahwa persentase penduduk yang mengalami keluhan kesehatan dari tahun 2003 hingga 2009 mengalami peningkatan, yakni $24,41 \%$ (2003), 26,51\% (2004), 26,68\% (2005), $28,15 \%$ (2006), 30,90\% (2007), 33,24\% (2008), $33,68 \%$ (2009). Berdasarkan keadaan tersebut kebutuhan masyarakat akan layanan kesehatan akan ikut meningkat. Salah satu outcome dari layanan kesehatan selain kesembuhan pasien adalah kepuasan pasien (Pohan, 2007).

Masyarakat pengguna pelayanan kesehatan pemerintah dan swasta semakin menuntut pelayanan yang bermutu. Tak dapat dipungkiri bahwa kini pasien semakin kritis terhadap pelayanan kesehatan dan menuntut keamanannya (Efendi, 2009). Pengguna jasa pelayanan kesehatan menginginkan pelayanan yang berkualitas, tidak hanya terkait kesembuhan dari penyakit secara fisik akan tetapi juga menyangkut kepuasan terhadap sikap, pengetahuan dan ketrampilan petugas dalam memberikan pelayanan. Tidak terkecuali dengan pasien di kelas 3 yang seharusnya mendapatkan pelayanan yang baik, (Khusnawati, 2010)

Ruang Dahlia merupakan ruang yang khusus digunakan untuk pelayanan pasien penyakit dalam kelas 3, dengan kapasitas tempat tidur berjumlah 20 serta jumlah pegawai dalam ruangan ini sebanyak 11 orang. Pada tahun 2015 angka kunjungan pasien rawat inap di Ruang Dahlia mencapai angka 1472. BOR (Bed Occupancy Ratio) kelas 3 di RSUD Kota Madiun mencapai angka 103,71\% dibandingkan standar Kemenkes yaitu 60 85\% (Departemen Kesehatan RI, 2005). Hal ini menunjukkan bahwa peminat kelas 3 di RSUD Kota Madiun sangat tinggi dibandingkan kelas 2, 1 maupun VIP. Berdasarkan latar belakang di atas, dilakukan penelitian tentang hubungan antara mutu pelayanan dan tingkat kepuasan pasien di instalasi rawat inap Dahlia, RSUD Kota Madiun.

\section{METODE PENELITIAN Jenis Penelitian}

Penelitian observasional analitik dengan menggunakan desain studi cross sectional.

\section{Tempat dan Waktu Penelitian}

Penelitian ini dilakukan di instalasi rawat inap Ruang Dahlia RSUD Kota Madiun pada bulan Oktober - Desember 2014 . 


\section{Populasi dan Sampel}

Populasi studi dalam penelitian ini yaitu pasien rawat inap di Ruang Dahlia tiga bulan terakhir mulai dari bulan Oktober sampai bulan Desember 2014 sebesar 410 orang.

Sampel yang diambil dalam penelitian ini sebanyak 78 responden dengan teknik purposive sampling.

\section{HASIL PENELITIAN}

Sebagian besar responden dalam penelitian ini berjenis kelamin laki-laki $(52,6 \%)$, berusia $50-64$ tahun $(44,9 \%)$, bekerja sebagai buruh $(29,5 \%)$, dan lebih dari separuh responden memiliki tingkat pendidikan tamat SD. Sebagian besar responden juga menyatakan bahwa mutu pelayanan di RS baik dan mereka puas dengan pelayanan tersebut.

Tabel 1. Karakteristik Responden di Instalasi Rawat Inap Ruang Dahlia RSUD Kota Madiun

\begin{tabular}{lcc}
\hline Variabel & Frekuensi & Persentase \\
\hline Jenis Kelamin & & \\
Laki-laki & 41 & 52,6 \\
Perempuan & 37 & 47,4 \\
Umur (tahun) & & \\
17-24 & 1 & 1,3 \\
$25-34$ & 13 & 16,7 \\
$35-49$ & 26 & 33,3 \\
$50-64$ & 35 & 44,9 \\
> 65 & 3 & 3,8 \\
Jenis Pekerjaan & & \\
Pelajar & 1 & 1,3 \\
PNS & 4 & 5,1 \\
Pegawai swata & 7 & 9,0 \\
Buruh & 23 & 29,5 \\
Pedagang & 13 & 16,7 \\
Tidak bekerja & 16 & 20,5 \\
Lain-lain & 14 & 17,9 \\
Tingkat & & \\
Pendidikan & & \\
SD & 41 & 52,6 \\
SLTP & 22 & 28,2 \\
SLTA & 13 & 16,7 \\
PT & 2 & 2,6 \\
Mutu Pelayanan & & \\
Baik & 44 & 56,4 \\
Tidak baik & 34 & 43,6 \\
Kepuasan Pasien & & \\
Puas & 41 & 52,6 \\
Tidak Puas & 37 & 47,4 \\
\hline
\end{tabular}

Hasil analisis bivariat dengan chisquare, menunjukkan bahwa pasien yang puas lebih banyak yang menyatakan bahwa mutu pelayanan Rumah Sakit sudah baik $(65,9 \%)$ dibandingkan yang menyatakan mutu Rumah Sakit kurang baik $(35,3 \%)$.

Berdasarkan nilai $\mathrm{p}$, terdapat hubungan yang signifikan antara mutu pelayanan dengan kepuasan pasien di instalasi Rawat Inap Dahlia RSUD Kota Madiun. Pasien yang menyatakan mutu pelayanan Rumah Sakit sudah baik memiliki peluang untuk merasa puas dengan pelayanan tersebut sebesar 3,54 kali lebih besar dibandingkan responden yang menyatakan bahwa mutu pelayanan Rumah Sakit kurang baik $(95 \%$ CI=1,39 - 9,07).

\section{PEMBAHASAN}

(Azwar, 2007) mengatakan mutu pelayanan kesehatan merupakan kesempurnaan suatu produk dalam pelayanan kesehatan yang dapat memuaskan setiap pemakai jasa. Pelayanan yang bermutu merupakan penyelenggaraan pelayanan yang diberikan sesuai dengan prosedur dan standar pada kode etik profesi yang telah ditetapkan, dengan menyesuaikan potensi dari sumber daya yang tersedia secara aman dan memuaskan yang dilakukan dengan wajar, efisien dan efektif dengan memperhatikan keterbatasan dan kemampuan pemerintah dan masyarakat konsumen.

Menurut peneliti, mutu pelayanan di RSUD Kota Madiun dapat dikatakan sudah baik hal ini karena persentase tertinggi untuk jawaban responden tentang mutu pelayanan terdapat pada kategori baik. Tetapi masih ada beberapa yang menilai bahwa mutu pelayanan di RSUD Kota Madiun masih belum baik, sehingga RSUD Kota Madiun seharusnya lebih meningkatkan lagi mutu pelayanan kepada masyarakat untuk memberikan mutu yang lebih baik dan dapat memberikan pelayanan yang sesuai dengan standar yang sudah ada.

Kepuasan terhadap sistem layanan kesehatan ditentukan oleh tiga sikap, yaitu pertama sikap terhadap fasilitas fisik dan lingkungan layanan kesehatan, kedua sikap terhadap sistem perjanjian termasuk menunggu giliran, waktu tunggu, pemanfaatan waktu selama menunggu, sikap mau menolong atau kepedulian personel, mekanisme pemecahan masalah dan keluhan yang timbul dan yang ketiga sikap terhadap lingkup dan sifat keuntungan dan layanan kesehatan yang 
ditawarkan. Beberapa uraian mengenai alasan ketidakpuasan pasien dapat dilihat dari distribusi frekuensi yang disusun berdasarkan teori RATER antara lain dari dimensi Reliability tentang pertanyaan prosedur penerimaan pasien secara cepat dan tidak berbelit, dimensi Responsiveness tentang pertanyaan perawat memperhatikan kebutuhan dan keluhan pasien, dimensi Asurance tentang pertanyaan perawat mampu melayani pasien, dimensi Empaty tentang pertanyaan perawat meningkatkan keamanan barang milik pasien dan dimensi Tangible tentang pertanyaan mengenai ruang rawat inap tertata bersih dan rapi (Kotler, 2007).

Tabel 2. Analisis Bivariat Mutu Pelayanan dengan Kepuasan Pasien di Instalasi Rawat Inap Ruang Dahlia RSUD Kota Madiun

\begin{tabular}{|c|c|c|c|c|c|c|c|c|}
\hline \multirow{2}{*}{$\begin{array}{c}\text { Mutu } \\
\text { pelayanan }\end{array}$} & \multicolumn{2}{|c|}{ Puas } & \multicolumn{2}{|c|}{ Tidak Puas } & \multicolumn{2}{|c|}{ Total } & \multirow{2}{*}{$\mathbf{p}$} & \multirow{2}{*}{$\operatorname{RP}(95 \% \mathrm{CI})$} \\
\hline & n & $\%$ & $\mathbf{n}$ & $\%$ & n & $\%$ & & \\
\hline Baik & 29 & 65,9 & 15 & 34,1 & 44 & 56,4 & \multirow{2}{*}{0,014} & \multirow{2}{*}{$\begin{array}{c}3,54 \\
(1,39-9,07)\end{array}$} \\
\hline Tidak Baik & 12 & 35,3 & 22 & 64,7 & 34 & 43,6 & & \\
\hline
\end{tabular}

Kepuasan pelanggan merupakan evaluasi terhadap surprise yang inheren atau melekat pada pemerolehan produk dan atau pengalaman konsumsi. Hasil analisis uji chisquare diperoleh nilai $\mathrm{p}=0,014$, dengan demikian maka dapat dikatakan bahwa ada hubungan antara mutu pelayanan dengan kepuasan pasien. Pasien yang menyatakan mutu pelayanan Rumah Sakit sudah baik memiliki peluang untuk merasa puas dengan pelayanan tersebut sebesar 3,54 kali lebih besar dibandingkan responden yang menyatakan bahwa mutu pelayanan Rumah Sakit kurang baik $(95 \% \mathrm{CI}=1,39$ - 9,07).

Hasil penelitian ini sesuai dengan penelitian yang dilakukan (Andriani, 2014) di Puskesmas Bukittinggi yang menyatakan bahwa ada hubungan antara mutu pelayanan poli umum puskesmas dengan kepuasan pasien $(\mathrm{p}=0,035)$. (Lupiyoadi, 2001) menyatakan bahwa faktor yang menentukan tingkat keberhasilan dan kualitas fasilitas pelayanan kesehatan akan menghasilkan pencapaian konsumen yang tinggi. Penelitian lain juga membuktikan bahwa tangible dan assurance berpengaruh terhadap kepuasan pasien di RS Sarila Husada Sragen, (Supartiningsih, 2017). Penelitian lain di Mamuju Utara menyatakan bahwa ada hubungan antara kualitas pelayanan (pendaftaran, dokter, perawat, farmasi, dan lingkungan) berhubungan dengan kepuasan pasien (Akbar, Fuad Husain, Burhanuddin Daeng Pasiga, 2017).

Dengan adanya hasil yang membuktikan adanya hubungan antara mutu pelayanan dengan kepuasan pasien, maka perlu ditingkatkan kembali mutu pelayanan yang ada guna untuk lebih memberikan suatu hasil yang lebih maksimal dan dapat memberikan rasa kepuasan yang seperti diharapkan oleh para masyarakat (Kotler, 2007).

\section{KESIMPULAN DAN SARAN}

Penelitian ini menunjukkan bahwa terdapat hubungan yang signifikan antara mutu pelayanan dengan kepuasan pasien di instalasi rawat inap Dahlia RSUD Kota Madiun. Pasien yang menyatakan mutu pelayanan Rumah Sakit sudah baik memiliki peluang untuk merasa puas dengan pelayanan tersebut sebesar 3,54 kali lebih besar dibandingkan responden yang menyatakan bahwa mutu pelayanan Rumah Sakit kurang baik.

Diharapkan pihak rumah sakit terus meningkatkan kualitas pelayanannya dalam penerimaan pasien secara cepat dan tidak berbelit-belit, selalu mengutamakan senyum sapa dan salam kepada pasien, memberikan pelayanan yang maksimal terhadap pasien, memberikan suatu kenyamanan tentang keamanan barang berharga pasien,dan selalu menjaga kebersihan dan kerapian ruang rawat inap di ruang Dahlia guna untuk memberikan kepuasan kepada pelanggan.

\section{DAFTAR PUSTAKA}

Akbar, Fuad Husain, Burhanuddin Daeng Pasiga, R. M. (2017). Association Between Service Health Quality and Patient Satisfaction-a Case Study of People in North Mamuju. International Journal of Management (IJM), 8(1), 168 - 
174.

Andriani, A. (2014). Hubungan Mutu Pelayanan Kesehatan dengan Kepuasan Pasien di Ruangan Poli Umum Puskesmas Bukittinggi. Journal Endurance, 2(1), 45 -52 .

Azwar. (2007). Menjaga Mutu Pelayanan Kesehatan. Jakarta: Pustaka Sinar.

Departemen Kesehatan RI. (2005). Standar Indikator Pelayanan di Rumah Sakit. Jakarta: Direktorat Jenderal Pelayanan Medik.

Departemen Kesehatan RI. (2010). Penerapan Standar Pelayanan Minimal di Rumah Sakit. Jakarta: Direktorat Jenderal Pelayanan Medik.

Efendi. (2009). Keperawatan Kesehatan Komunitas Teori dan Praktek Dalam
Keperawatan. Jakarta: Salemba Medika. Khusnawati. (2010). Analisis Kepuasan Pasien terhadap Pelayanan pada Puskesmas Sungai Durian, Kabupaten Kubu Raya. Universitas Hasanuddin, Makassar.

Kotler, P. (2007). Manajemen Pemasaran (Kedua Bela). Jakarta: Indeks.

Lupiyoadi, R. (2001). Manajemen Pemasaran Jasa. Jakarta: Salamba Empat.

Pohan. (2007). Jaminan Mutu Layanan Kesehatan. Jakarta: Buku Kedokteran EGC.

Supartiningsih, S. (2017). Kualitas Pelayanan dan Kepuasan Pasien Rumah Sakit: Kasus pada Pasien Rawat Jalan. Jurnal Medicoeticolegal Dan Manajemen Rumah Sakit, 6(1), $1-6$. 